\title{
Characterisation OF Water VAPOUR Transmission Behaviour OF WOVEN FABRICS
}

\author{
R. P. Jamdagni ${ }^{1}$; S. Bhattacharya; N. Kumar \\ The Technological Institute of Textile and Sciences, Bhiwani, Haryana, India \\ e-mail: ${ }^{1}$ rjamdagni@ hotmail.com
}

\begin{abstract}
The study investigates the dynamic water vapour transmission behaviour of woven fabrics and its correlation with the steady state behaviour. An indigenously fabricated instrument was used for testing the dynamic behaviour, while the standard cup method was used for testing the steady state behaviour. Woven fabrics made of ring spun yarns and having blends of $100 \%$ cotton, cotton/bamboo, cotton/polyester and polyester/bamboo at different blend percentages were prepared. Fabrics samples were prepared under each blend at two and three different levels of warp and weft densities respectively. Dynamic response variables of 'slope,' 'time' and dynamic WVTR were calculated from the plots of partial vapour pressure versus time obtained from the dynamic study of each fabric sample.
\end{abstract}

\section{Introduction}

Textile as a clothing material is an integral part of human life, the primary role being to form a layer of barrier that protects the body against unsuitable environments by avoiding mechanical, thermal, and chemical damages, and maintaining its thermal balance that is essential for its survival. The psychological response of a human body to a given combination of clothing and environmental conditions is predictable and can be calculated easily from measurable factors, such as thermal and moisture resistance of clothing, the climatic conditions and level of physical activities. This forms the traditional research area into clothing comfort in which a large number of research papers has been published till date.

To determine the comfort characteristics of any particular fabric, it is essential to assess the properties of fabric that may have some bearing with the psychological, physiological and physical factors. The importance of thermal and moisture dynamic measurements is that stimuli of an uncomfortable sensation arise during the transient state. In some fabrics warmth sensation might be felt at a particular time but after some time it might not be felt so strongly. Therefore, this differentiation between the fabrics would not be possible if the tests were performed only at equilibrium. On the other hand, the steady state method provides good moisture transfer data; however, they cannot explain wetness or moisture related subjective sensations that determine human comfort. Consequently, dynamic water vapour transfer through fabrics has recently received special attention in comfort assessment of textile fabrics. $[1,2]$

The dynamic transmission properties can be characterized as percentage moisture collected, dynamic surface wetness, water vapour pressure and thermal insulation. The instruments for assessing the dynamic moisture and thermal transmission properties are dynamic water vapour transmission tester, cobaltous chloride method, water permeability tester, controlled dish apparatus, etc. Some studies on dynamic thermal and moisture transmission properties are carried out by different researchers. [3, 4, 5, 6, 7, 8, 9, 10] Kim J. and Spivak S. [11] used microfine hygrometry and thermometry to measure dynamic changes in moisture vapour pressure and temperature on both surfaces of the layered fabric assembly made of $100 \%$ 
cotton and $100 \%$ polyester under simulated body clothing conditions. Hong K., Hollies N. and Spivak S. [12] studied cotton, polyester and a blend in plain woven, pure finish fabrics to determine their influence on dynamic surface wetness and moisture transfer through textiles. The dynamic moisture movement on the fabric surface next to the skin is observed by a chemical moisture indicator. Wang J. and Yasuda H. [13] used a vapour method and a sweat method to study the transport of water vapour emanating from liquid water in contact with the bottom layer of the fabric through several fabrics made of $100 \%$ polyester and $100 \%$ polypropylene. Scheurell D., Spivak S. and Hollies N. [3] found that dynamic surface wetness of fabrics has been found to correlate with skin contact comfort in wear for a variety of fabric types suggesting that mobility of thin films of considered moisture is an important element of wearing comfort. They used $100 \%$ cotton, $100 \%$ polyester and $50 / 50$ polyester cotton blend knitted shirting fabrics. The percentage of moisture collected is observed by a dynamic surface moisture device. There is, however, a lack of systematic study on water vapour transport behaviour of woven fabrics and the extent of the effect of different yarn and fabric constructional parameters on such behaviour. This study thus aims at characterization of dynamic water vapour transmission behaviour of woven fabrics and its correlation with the steady state behavior. It also aims at studying the effect of relevant parameters like fibre type, blend composition and percentage, yarn count and fabric constructional parameters on the transport properties.

\section{$1 \quad$ Materials and Test Methods}

\subsection{Materials}

Yarn samples were prepared from cotton, polyester and bamboo fibres having a staple length of $29.2 \mathrm{~mm}, 38 \mathrm{~mm}$ and $38 \mathrm{~mm}$ respectively, and fineness of 4.35 micron, 1.2 denier and 1.4 denier respectively. The raw material was manually opened and mixed to form blends of $100 \%$ cotton, cotton/bamboo (70/30, 50/50 and 30/70 blend percentages), cotton/polyester (70/30 and 30/70 blend percentages) and polyester/bamboo (70/30 and 30/70 blend percentages). Carded yarns were produced from each of the above blends in Lakshmi Rieter G5/1 ring frame at a spindle speed of $14500 \mathrm{rpm}$ and TM of 4.0. The yarn counts produced were $2 / 46$ and $2 / 30 \mathrm{Ne}$ to be used as warp, and $23 \mathrm{Ne}$ and $15 \mathrm{Ne}$ to be used as the corresponding weft for production of woven fabrics. The double yarns were produced in a ring doubling machine at a twist level of $70 \%$ of the single yarn twist. Plain woven fabrics were produced in a sample weaving machine with two different levels of warp density (18.9 and 23.6 ends per $\mathrm{cm}$ for the $2 / 30 \mathrm{Ne}$ and $2 / 46 \mathrm{Ne}$ warp respectively) and three different levels of weft density $(17.3,18.9 \& 20.5$ picks per $\mathrm{cm}$, and $22,23.6 \& 25.2$ picks per $\mathrm{cm}$ for the $15 \mathrm{Ne}$ weft and $23 \mathrm{Ne}$ weft respectively). Accordingly, six different fabric samples were produced per blend giving a total of forty eight different fabric samples for all of the eight different blends. All fabric samples were subsequently soap washed, air dried and preconditioned for $24 \mathrm{hrs}$ in standard atmospheric conditions (BS EN 20139, for tropical regions) of $27 \pm 20 \mathrm{C}$ temperature and $65 \pm 2 \% \mathrm{R}$.H before testing.

The yarn samples were tested for their actual linear density using a wrap reel and an electronic balance, and the actual yarn diameter was measured for each yarn sample on Leica Q500 MC projection microscope at 100 randomly selected places along the length of the yarn. Accordingly, yarn packing coefficients were calculated as the ratio of the yarn and fibre densities as per Equations (1), (2) \& (3) given below:

$$
\text { Yarn Packing Coefficient }=\text { yarn density / fibre density, }
$$

where 
Yarn density = weight $($ gram $) /$ volume (c.c.) of 120 yds length of yarn,

Volume of 120 yds length of yarn $=91.44 \times 120 \times \pi \times d^{2} / 4 \mathrm{~cm}^{3}$,

where $d$ is the measured yarn diameter in $\mathrm{cm}$, and fibre density is considered to be 1.54 gram/c.c., 1.38 gram/c.c. and 1.67 gram/c.c. (standard for cotton, polyester and bamboo respectively). [14]

Each fabric sample was tested for the actual sett, thickness and areal density. While the actual fabric sett was measured by manually counting the threads by the help of a pick glass, the thickness was measured at a pressure level of $5 \mathrm{gf} / \mathrm{cm}^{2}$ and the areal density was measured as per ASTM standard procedure. [15] The fraction cover of yarn in fabric $\left(K_{f}\right)$ was calculated from the measured average yarn diameter and yarn spacing in the fabric as per Equation (4) given below:

$$
K_{f}=\frac{d_{1}}{p_{1}}+\frac{d_{2}}{p_{2}}-\frac{d_{1} \cdot d_{2}}{p_{1} \cdot p_{2}},
$$

where

$d_{1}$ and $d_{2}$ are the measured average warp and weft diameters respectively and $p_{1}$ and $p_{2}$ are the measured average warp and weft spacing in fabric respectively.

Water vapour permeability (steady state) of the fabric samples was measured by the help of the upright cup method as per ASTM standard procedure.16 On the other hand, dynamic water vapour transmission behaviour of the fabric samples was assessed by the help of an indigenously developed apparatus as described below. 


\subsection{Dynamic water vapour and thermal transmission apparatus}

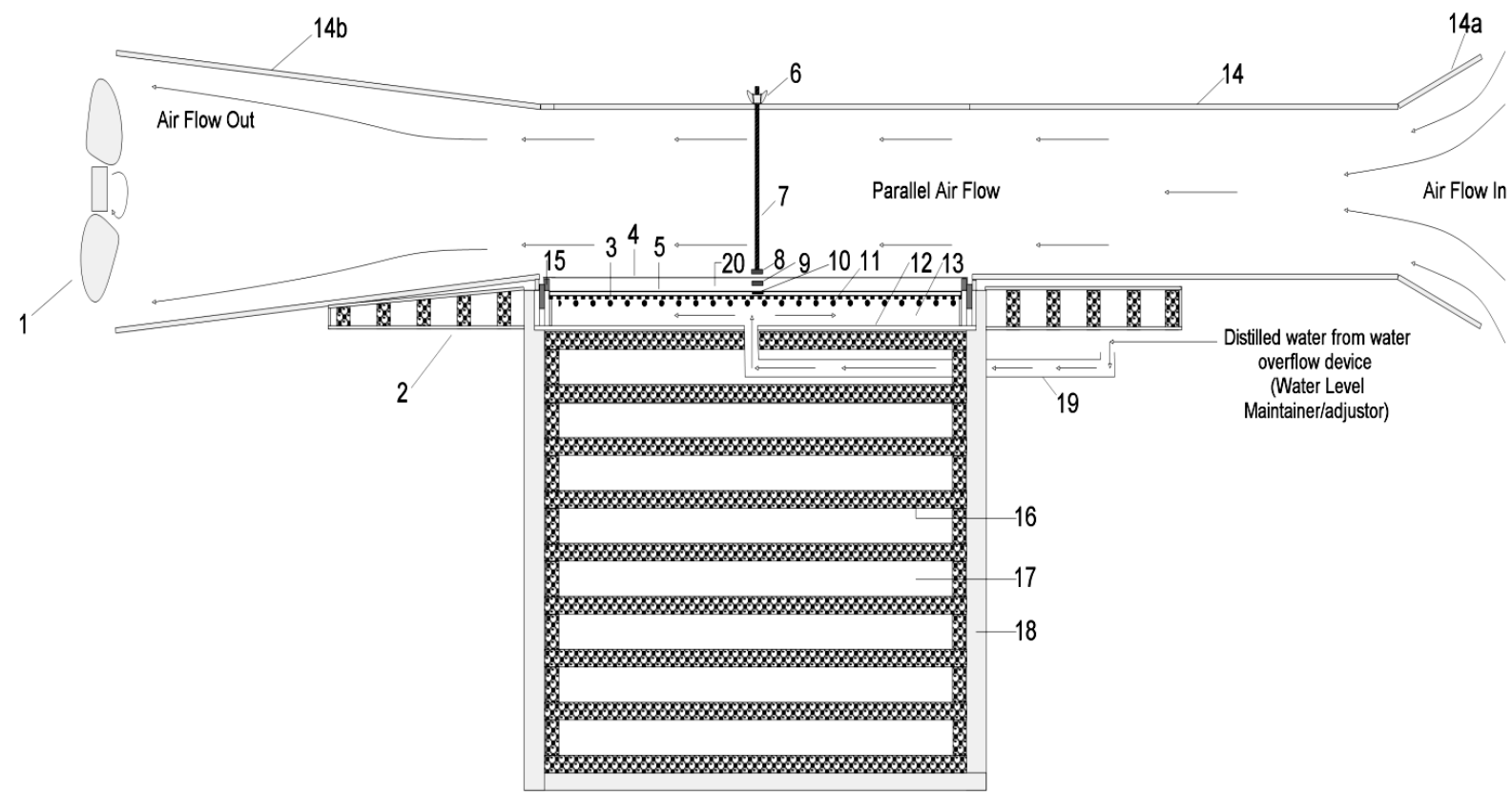

[1-Variable speed axial fan; 2-Side reflective insulation; 3-Perforated steel plate; 4-Fabric sample; 5-Non woven fabric; 6-Winged nut; 7-Threaded rod; 8-Top humidity and temperature sensors; 9-Bottom humidity and temperature sensors; 10-Temperature sensor for nonwoven fabric; 11-Electrical heating coil; 12-Test tray; 13Distilled Water; 14-Air tunnel, 14a-contractor portion, 14b-diffuser portion; 15-Spacer; 16-Expanded polystyrene board (covered with aluminum foil on both sides); 17-Air gap; 18-Wooden case containing bottom reflective insulation; 19-Tube connection to test tray; 20-Microclimate.]

Source: Own

Fig. 1: Cross sectional view of the instrument

The apparatus designed and developed is capable of assessing the transient water vapour and thermal transmission behaviour combined as well as dry heat transmission characteristics under both convective and non-convective conditions. It simulates the sweating skin condition by the help of a perforated plate and a non-woven fabric with an adjustable degree of wetness and temperature, and the skin-fabric microclimate by the help of appropriately designed spacers. Reproducible and tangential wind flow conditions are generated by the help of a suitably designed wind tunnel.

The apparatus, as shown in Figure 1, consists of a square shaped test tray providing a test area of $0.0678 \mathrm{~m}^{2}$. The mouth of the test tray is covered by a finely perforated steel plate above which a $3 \mathrm{~mm}$ thick thermal bonded polypropylene non-woven fabric is placed simulating the skin. The test tray is filled with distilled water by the help of a tube connection, so the top surface of the water remains in contact with the perforated steel plate and thus, wets the nonwoven fabric. The level of the water inside the test tray is always maintained at the required constant value by the help of a suitably designed water overflow device/water level maintainer which is connected to the test tray by a tube connection. The level of the water in the overflow device can be adjusted in order to adjust the level of water in the test tray and, hence, the degree of wetness of the non-woven fabric top surface. Nichrome heating coils are laid in a suitable arrangement just below the perforated steel plate being connected to a variable voltage electric supply device. The heating coils are capable of heating the nonwoven fabric to the skin temperature range $\left(33-35^{\circ} \mathrm{C}\right)$ with an input voltage range of 20 to 25 volts as read by the help of a digital volt meter. A temperature sensor (Platinum Resistance Thermometer, type PT100) is located just below the non-woven fabric top surface and is 
further connected to a digital temperature controller that monitors and maintains the nonwoven fabric temperature at the required value. The test tray assembly is mounted on the top of an air tight wooden casing that contains the side and bottom reflective insulations. Reflective insulation17 is considered a desirable alternative to common mass insulations and greatly effective in our case with minimal radiative, conductive and convective heat losses allowed by it. It is designed in a way that the bottom and lateral heat losses from the test tray are limited to maximum around $7-8 \%$ of the heat flux through the fabric sample. Unidirectional and perpendicular heat flow condition upwards through the fabric sample may thus be approximated. The insulation consists of the appropriate amount of aluminium foil (with bright finish) covered expanded polystyrene boards maintained parallel to the sides of the test tray and at appropriate spacing from each other. To assess convective effects, tangential and reproducible wind flow conditions may be created over the test area by the help of the wind tunnel and the variable speed axial fan. The contractor and the diffuser portions are provided in the wind tunnel in order to form a steady and parallel air flow with minimum turbulence.

The test fabric sample is mounted over the test area by the help of a spacer that maintains a fixed gap between the fabric sample and the non-woven fabric surface. This gap, simulating the skin-fabric microclimate, may be adjusted to $4 \mathrm{~mm}, 8 \mathrm{~mm}$ and $12 \mathrm{~mm}$ by selecting the appropriate spacer. The fabric sample of an appropriate size may be mounted on the spacer without any sagging by the help of adhesive tapes. Upper and lower thermo-hygro sensors (Temperature sensor: Platinum Resistance Thermometer, type PT100 - flexible platinum wire element with temperature range up to $200{ }^{\circ} \mathrm{C}$, response time in the order of 0.2 seconds and accuracy in the order of 20-200mK; Humidity sensor: Bulk Polymer Resistive type, relative humidity range $0-100 \%$, response time in the order of $30-60$ seconds for $63 \%$ RH step change and accuracy in the order of 2-3\%) are located just over and below the test fabric sample respectively to monitor the temperature and relative humidity over time in the microclimate as well as over the fabric surface. Each sensor is electrically connected to respective digital meters that display the instant temperature and relative humidity values with a sufficient degree of accuracy.

Before carrying out tests, the test area was levelled to a horizontal disposition by the use of a standard spirit level in order to achieve uniform wetting of the non-woven fabric. The test tray was filled with distilled water and the water level controlled whether o the non-woven fabric was just wetted with a thin film of water appearing on its top surface. The input voltage to the heater was adjusted to get a steady temperature of around $33{ }^{\circ} \mathrm{C}$ for the non-woven fabric and all the meters were switched on. The apparatus was kept on in this condition for a period of about 30 minutes under standard atmospheric conditions of $27 \pm 2{ }^{\circ} \mathrm{C}$ temperature and $65 \pm$ $2 \%$ R.H. for steadying of the readings. Relative humidity readings from the upper and lower sensors were started to be taken immediately after mounting of the fabric samples at regular time intervals for a period of around 60 minutes for each sample. Non-convective condition was maintained for the study and three samples of each fabric were tested by using the $8 \mathrm{~mm}$ spacer. The relative humidity values obtained were converted into vapour pressure values using a psychrometric calculator. Accordingly, graphical plots of vapour pressure versus time for both the upper and lower sensors were constructed for each fabric sample and analyzed for comparative assessment of the transient behaviour. Additionally, the following dynamic parameters were calculated for an analysis and interpretation.

1. Slope of the plots in the initial period of 0 to 10 minutes. Such slopes represent the early response to the placement of the fabric. Such early response is important since initial changes in water vapour pressure are important in evaluating the subjective comfort. [12] 
2. Time to reach $75 \%$ of the total change in partial pressure. This variable gives a measure of the extent of change in relative humidity and temperature after the initial response. [12]

\section{$2 \quad$ Results and Discussion}

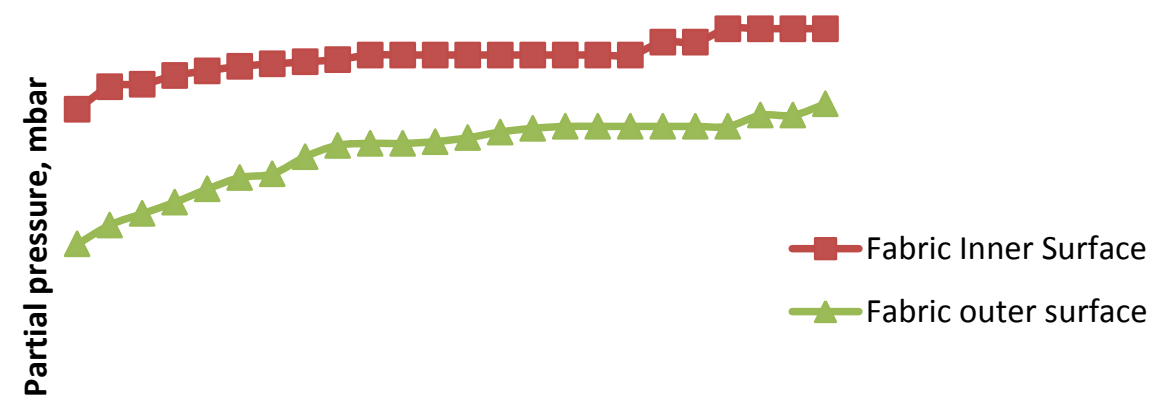

Time, $\min$

Source: Own

Fig. 2: Variation of partial vapour pressure with time for $100 \%$ cotton blend (sample code $\left.S_{11}\right)$

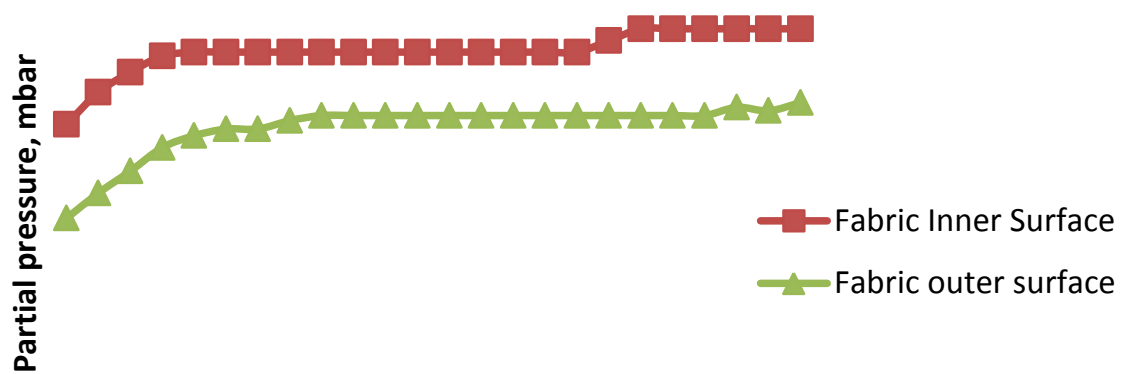

Time, $\min$

Source: Own

Fig. 3: Variation of partial vapour pressure with time for $70 / 30$ cotton/bamboo (sample code $S_{31}$ )

\subsection{Dynamic state water vapour transmission behaviour}

The dynamic WVTR values show the same trend of WVTR values as that of the steady state with the more hydrophilic blend exhibiting higher WVTR values. Furthermore, increasing the bamboo percentage in cotton/bamboo and polyester/bamboo blends and decreasing the polyester content in the cotton/polyester blends led to higher WVTR values. Thus, the effect of hydrophilicity also dominates over the opposite effect of yarn packing fraction values here.

The dynamic variable "slope" is found to be highest for the cotton/polyester blend followed by the polyester/bamboo, 100\% cotton and cotton/bamboo blends. Being the most hydrophilic blend, cotton/bamboo acts as a good buffer due to its higher moisture absorption ability. This leads to the higher moisture absorption by the cotton/bamboo blend fabric, thus slowing down the moisture build-up within the microclimate. A smaller value of the slope is thus obtained with a slower rate of increase of the partial pressure within the microclimate. In this case the 
effect of the increased moisture within the microclimate is less severe and the wearer is likely to feel more comfortable. Accordingly, the cotton/bamboo blend is the most comfortable one followed by $100 \%$ cotton, polyester/bamboo and cotton/polyester. The effect of the blend ratio on the slope follows the same trend of hydrophilicity. Increasing the bamboo content in the cotton/bamboo and polyester/bamboo blends while decreasing the polyester content in the cotton/polyester blend leads to a decreased slope and hence increased comfort. The dynamic variable of "time" is found to be the highest in the case of the cotton/bamboo blend followed by $100 \%$ cotton, polyester/bamboo and cotton/polyester. This is again expected as well, since the cotton/bamboo blend, being the most hydrophilic, has a higher moisture absorption ability, thus slowing down the rate of moisture build-up within the microclimate. This leads to a greater time to reach a certain moisture level within the microclimate. Here again, due to the better buffering ability of the more hydrophilic blend, the wearer is likely to feel more comfortable. Accordingly again, cotton/bamboo is the most comfortable followed by $100 \%$ cotton, polyester/bamboo and cotton/polyester. The effect of the blend ratio on time follows the same trend of hydrophilicity.

\section{Conclusion}

The study focuses on the water vapour transmission behaviour (steady as well as dynamic) of woven fabrics with different blends of cotton, cotton/bamboo, cotton/polyester and polyester/bamboo and with different yarn and fabric constructional parameters. Under both steady and dynamic conditions, the cotton/bamboo blend gave the highest WVTR value followed by $100 \%$ cotton, polyester/bamboo and cotton/polyester. Increasing bamboo percentage in cotton/bamboo and polyester/bamboo blends and decreasing the polyester content in cotton/polyester blends led to higher WVTR values. Therefore, hydrophilic fibres, having a greater ability to absorb moisture, facilitate the absorption and diffusion of water vapour through the fabric substrates. This effect also seems to dominate the opposite effect of yarn packing fraction values. The dynamic variables 'slope' and 'time' follow the same trend of hydrophylicity with the decreasing slope and increasing time with increased hydrophylicity of the blend. The decreased fabric fraction cover and fabric thickness as well as the increased yarn packing fraction value led to the increased WVTR value under both steady and dynamic conditions for all blends. In general, the increased fabric thickness and fraction cover led to the increased dynamic variable 'slope' and decreased dynamic variable 'time.'

Linear regression equations relating water vapour transmission rate with MR\%, yarn packing fraction, fabric thickness and fraction cover were developed. The equations gave a sufficiently high correlation coefficient (0.9) between the actual and estimated values indicating that they may be used for effective predictions of the water vapour transmission rate from the given yarn and fabric parameters. From the developed regression equations it is observed that MR\% and yarn packing fraction have a positive correlation, while the fabric thickness and fraction cover have a negative correlation with the water vapour transmission rate under both steady and dynamic conditions. Both steady and dynamic state WVTR values display a similar dependency on the yarn and fabric parameters. In both cases the fabric fraction cover is found to be the single most important factor influencing the transmission rate. This effect of the fraction cover is found to be more significant in the dynamic state. This is followed by the influence of the fabric thickness, yarn packing fraction and MR\%. The influence of MR\% is, however, found to be greater in the case of the dynamic state. This indicates that the fabric cover and the hydrophylicity of the blend play a more significant role in dynamic conditions compared to steady state conditions. 


\section{Literature}

[1] DAS, A: Objective evaluation of comfort characteristics of textiles. One day seminar on comfort in textiles. IIT, Delhi, October 16, 2004, 69-87.

[2] KOTHARI, V. K.: Thermophysiological comfort characteristics and blended yarn woven fabrics. Indian J. of Fibre \& Text. Res. Vol. 31, March 2006, 177-186.

[3] SCHEURELL, D. M.; SPIVAK, S. M. \& HOLLIES, N. R. S.: Dynamic surface wetness of fabrics in relation to clothing comfort. Text. Res. J. July 1985, 349-399.

[4] REES, W. H.: Measurement of the water vapour permeability of textile fabrics. $J$. of Text. Inst. 32, 1941, t/149.

[5] STUART, I. M. \& DENBY, E. F.: Wind indueed transfer of water vapour \& heat through clothing. Text. Res. J. November 1983, 655.

[6] GIBSON, P. W.: Factors influencing steady state heat \& water vapour transfer measurements for clothing materials. Text. Res. J. 63 (12), 1993, 749-764.

[7] SREENIVASAN, S.; NACHANE, R. P.; PATEL, G. S.; CHINDAMBARESWARAN, P. K. \& PATIL, N. B.: Parameters related to clothing comfort - diffusive moisture transport evaluation. Indian J. of Fibre \& Text. Res. Vol. 16, September 1991, 189-194.

[8] WEHNER, J. A.; MILlER, B. \& REBENFELD, L.: Dynamics of water vapour transmission through fabric barriers. Text. Res. J. October 1988, 581-592.

[9] FOURT, L. \& HARRIST, M.: Diffusion of water vapour through textiles. Text. Res. J. May 1947, 256-263.

[10] FARNWORTH, V. \& DOLHAN, P. A.: An apparatus to measure water vapour resistance of textiles. J. of Text. Inst. 75 (2), 1984, 142-145.

[11] KIM, J. O. \& SPIVAK, S. M.: Dynamic moisture vapour transfer through textiles, Part II. Text. Res. J. February 1994, 112-121.

[12] HONG, K.; HOLLIES, N. R. S. \& SPIVAK, S. M.: Dynamic moisture vapour transfer through textiles, Part I. Text. Res. J. December 1988, 697-706.

[13] WANG, J. H. \& YASUDA, H.: Dynamic water vapour \& heat transport through layered fabrics, Part I. Text. Res. J. January 1991, 10-20.

[14] GUPTA, V. B. \& KOTHARI, V. K.: Manufactured Fibre Technology (Chapman and Hall, London), 1997, 1-13.

[15] ASTM D 3776, Standard test methods for mass per unit area (weight) of fabric.

[16] ASTM E 96-80, Standard test methods for water vapour transmission of materials.

[17] GUYER, E. C. \& BROWNELL, D. L.: Handbook of Applied Thermal Design. Taylor \& Francis Inc., London, U.K., 1999, 3-47.

[18] QU, J. \& RUCKMAN, J.: A new calculation method of water vapour permeability at unsteady state. J. of Text. Inst. Vol. 97 (5), 2006, 449-453.

R. P. Jamdagni; S. Bhattacharya; N. Kumar 


\section{POPIS CHOVÁNÍ TKANIN PŘI TRANSMISI VODNÍ PÁRY}

Studie zkoumá chování tkanin při dynamické transmisi vodní páry a jeho korelaci s ustáleným chováním. Pro testování dynamického chování byl použit vlastnoručně vyrobený nástroj, zatímco pro testování chování v ustáleném stavu byla použita standardní „cup“ metoda. Byly připraveny vzorky tkanin vyrobených na prstencových skacích strojích a směsi ze $100 \%$ bavlny, bavlna/bambus, bavlna/polyester a polyester/bambus $\mathrm{v}$ různých procentech prolnutí. Vzorky byly připraveny $\mathrm{v}$ rámci každé směsi ve dvou a třech různých úrovních dostavy osnovy a útku. Dynamické proměnné ,sklon“, „čas“ a dynamické WVTR byly vypočteny $\mathrm{z}$ velikosti plochy, na kterou působí parciální tlak páry $\mathrm{v}$ závislosti na čase, získané z dynamické studie každého vzorku tkaniny.

\section{BESCHREIBUNG DES VERHALTENS GEWOBENER TEXTILIEN BEI WASSERDAMPFÜBERTRAGUNG}

Diese Studie untersucht das dynamische Verhalten gewobener Textilien bei Wasserdampfübertragung und deren Wechselwirkung mit dem Verhalten im stabilen Zustand. Zum Testen dieses dynamischen Verhaltens wurde ein eigens dafür erzeugtes Instrument verwendet, wobei die Standardmethode zum Testen des Verhaltens im stabilen Zustand herangezogen wurde. Es wurden gewobene Textilien aufbereitet, die aus ringgesponnenem Garn erzeugt sind und Mischungen von hundertprozentiger Baumwolle, Baumwolle/Bambus, Baumwolle/Polyester und Polyester/Bambus in verschiedenen Mischverhältnissen aufweisen. Textilmuster in jeder Mischung auf zwei und drei verschiedenen Ebenen von Kettfäden bzw. Schussfäden wurden aufbereitet. Es wurden dynamische Reaktionsvariablen von „Neigung“, „Zeit" und dynamisches WVTR ausgehend von den Schemata partiellen Dampfdrucks versus Zeit aus der dynamischen Studie jedes Textilmusters gewonnen.

\section{OPIS ZACHOWANIA TKANIN PRZY TRANSMISJI PARY WODNEJ}

Opracowanie poświęcone jest zachowaniu tkanin w czasie dynamicznej transmisji pary wodnej $\mathrm{i}$ jego skorelowania $\mathrm{z}$ zachowaniem ustabilizowanym. Do celów testowania zachowania dynamicznego zastosowano własnoręcznie wykonane narzędzie, natomiast do testowania zachowania w stanie ustabilizowanym zastosowano standardową metodę „cup”. Przygotowano próbki tkanin wyprodukowanych na skręcarkach obrączkowych i mieszanki z 100\% bawełny, bawełna/bambus, bawełna/poliester oraz poliester/bambus z różnymi procentowymi udziałami. Próbki przygotowano w ramach każdej mieszanki w dwóch i trzech różnych gęstościach osnowy i wątku. Dynamiczne zmienne „nachylenie”, „czas” oraz dynamiczna WVTR (przepuszczalność pary wodnej) obliczono na podstawie wielkości powierzchni, na którą działa cząstkowe ciśnienie pary w zależności od czasu, uzyskanej z dynamicznego badania każdej próbki tkaniny. 